OPEN ACCESS

Edited by:

Xiaomin $\mathrm{Li}$

Fudan University, China

Reviewed by:

Peiyuan Wang,

Fujian Institute of Research on the

Structure of Matter (CAS), China

Liang Chen,

Fudan University, China

*Correspondence:

Ningtao Liu

ningt_liu@163.com

Jianwei Fan

fanjianwei@tongji.edu.cn

Specialty section:

This article was submitted to

Nanoscience,

a section of the journal

Frontiers in Chemistry

Received: 06 January 2020 Accepted: 12 March 2020

Published: 21 April 2020

Citation:

Wang Y, Lv M, Chen Z, Deng Z, Liu N, Fan J and Zhang W (2020) A Fluorescence Resonance Energy Transfer Probe Based on DNA-Modified Upconversion and Gold Nanoparticles for Detection of Lead lons. Front. Chem. 8:238 doi: 10.3389/fchem.2020.00238

\section{A Fluorescence Resonance Energy Transfer Probe Based on DNA-Modified Upconversion and Gold Nanoparticles for Detection of Lead Ions}

\author{
Yue Wang ${ }^{1}$, Menghua $\mathrm{Lv}^{1}$, Zehan Chen ${ }^{1}$, Zilong Deng ${ }^{1}$, Ningtao Liu ${ }^{2 *}$, Jianwei Fan ${ }^{1,3^{*}}$ and \\ Weixian Zhang ${ }^{1,3}$
}

${ }^{1}$ State Key Laboratory of Pollution Control and Resources Reuse, College of Environment Science and Engineering, Tongji University, Shanghai, China, ${ }^{2}$ Department of Neurosurgery, Shanghai Tongji Hospital Affiliated to Tongji University, Shanghai, China, ${ }^{3}$ Shanghai Institute of Pollution Control and Ecological Security, Shanghai, China

We report a new sensor for the specific detection of lead ions $\left(\mathrm{Pb}^{2+}\right)$ in contaminated water based on fluorescence resonance energy transfer (FRET) between upconversion nanoparticles (UCNPs) as donors and gold nanoparticles (Au NPs) as receptors. The UCNPs modified with $\mathrm{Pb}^{2+}$ aptamers could bind to Au NPs, which were functionalized with complementary DNA through hybridization. The green fluorescence of UCNPs was quenched to a maximum rate of $80 \%$ due to the close proximity between the energy donor and the acceptor. In the presence of $\mathrm{Pb}^{2+}$, the FRET process was broken because $\mathrm{Pb}^{2+}$ induced the formation of G-quadruplexes from aptamers, resulting in unwound DNA duplexes and separated acceptors from donors. The fluorescence of UCNPs was restored, and the relative intensity had a significant linear correlation with $\mathrm{Pb}^{2+}$ concentration from 0 to $50 \mathrm{nM}$. The sensor had a detection limit as low as 4.1 nM in a buffer solution. More importantly, the sensor exhibited specific detection of $\mathrm{Pb}^{2+}$ in complex metal ions, demonstrating high selectivity in practical application. The developed FRET prober may open up a new insight into the specific detection of environmental pollution.

Keywords: upconversion nanoparticles, gold nanoparticles, fluorescence resonance energy transfer, DNA, lead ions

\section{INTRODUCTION}

Lead ion $\left(\mathrm{Pb}^{2+}\right)$, one of the most serious metallic toxicants, can damage cardiovascular, reproductive, neurological, and developmental systems of the human body at low concentrations in the blood (Yoosaf et al., 2007; Zhou et al., 2011; Kim et al., 2012; Li et al., 2013). Although traditional methods including inductively coupled plasma mass spectrometry (Xia et al., 2008; Gao et al., 2009), atomic absorption spectroscopy (Bravo-Sanchez et al., 2001), and high-performance liquid chromatography (Yang et al., 2003) are highly sensitive and accurate, complicated pretreatment, and implementation limit their applicability for on-site rapid detection. Therefore, it is of important significance to develop analytical strategies with facile and straightforward features. 
The detection assay composed of fluorescence and DNA molecules has attracted more and more attention mainly due to sensitive fluorescence signal, stable DNA molecules, and highly specific binding ability between specific sequences and target detectors (e.g., protein, ions, virus, and nucleic acid aptamers) (Hamaguchi et al., 2001; Pavlov et al., 2004; Xiao et al., 2005; Chang et al., 2010; Saha et al., 2012). Zhou and co-workers labeled 6-carboxyfluorescein on G-rich DNA strands and monitored the reduction of fluorescence for $\mathrm{Pb}^{2+}$ detection (Zhan et al., 2013). Shi and co-workers developed a new strategy based on DNA-templated silver nanoclusters with elevated fluorescence for L-histidine detection (Zheng et al., 2015). However, reported substances or quenchers in the actual environment might weaken the fluorescence and lead to falsepositive results. Therefore, the "turn-off-on" detection system based on fluorescence resonance energy transfer (FRET) is introduced to avoid external interferences.

Upconversion nanoparticles (UCNPs) have rapidly emerged owing to their unique luminescent properties (Wang et al., 2005; Mader et al., 2010; Haase and Schaefer, 2011; Chen et al., 2014). Compared to traditional fluorescent markers, the UCNPs presented low auto-fluorescence, narrow emission width, no flicker, and strong light stability, leading to a wide application in biological and environmental monitoring and sensing (Chen and Zhao, 2012; Chen et al., 2013, 2014; Dacosta et al., 2014). Therefore, upconversion luminescence, as sensing signal under excitation of the near-infrared ray (NIR) light, effectively diminished the background noise in a complicated detection system (Wu et al., 2014). Meanwhile, gold nanoparticles (Au NPs) are superior fluorescence quenching agents due to the large extinction coefficient and a wide absorption band in the UVvisible region (Peng et al., 2011; Lin et al., 2013; Liu et al., 2013). The FRET systems were established based on upconversion nanoparticles and gold nanoparticles for the detection of avidin and $\mathrm{Cr}^{3+}$ (Wang et al., 2005; Liu et al., 2013).

In this paper, $\mathrm{NaYF}_{4}: \mathrm{Yb}, \mathrm{Er} @ \mathrm{NaYF}_{4} \mathrm{UCNPs}$ as energy donors and Au NPs as energy receptors are employed as FRET system for the sensitive detection of $\mathrm{Pb}^{2+}$. The donors and receptors are paired by two complementary DNA strands with good quenching ability for UCNPs. Single-stranded DNA for modifying UCNPs is rich in $\mathrm{G}$ base, which can fold to G-quadruplex structure in the presence of $\mathrm{Pb}^{2+}$. DNA duplex is then disrupted and the FRET system between UCNPs and Au NPs is cleaved, resulting in the restoration of fluorescence. The concentration of $\mathrm{Pb}^{2+}$ can be detected by monitoring the fluorescence recovery.

\section{MATERIALS AND METHODS}

\section{Materials}

Anhydrous yttrium trichloride $\left(\mathrm{YCl}_{3}, 99.99 \%\right)$, anhydrous ytterbium trichloride $\left(\mathrm{YbCl}_{3}, 99.9 \%\right)$, anhydrous erbium chloride $\left(\mathrm{ErCl}_{3}, 99.99 \%\right)$, 1-octadecene (ODE, 90\%), oleic acid (OA, $90 \%)$, sodium hydroxide $(\mathrm{NaOH}, 96 \%)$, and ammonium fluoride $\left(\mathrm{NH}_{4} \mathrm{~F}, 96 \%\right)$ were purchased from Sigma-Aldrich. Trihydroxy methyl aminomethane (Tris), $\mathrm{HCl}, \mathrm{NaCl}, \mathrm{KCl}, \mathrm{CaCl}_{2}, \mathrm{MgCl}_{2}$, $\mathrm{CuCl}_{2}, \mathrm{ZnCl}_{2}$, and $\mathrm{FeCl}_{3}$ were obtained from Sinopharm. All chemicals were used directly without any further purification.
Deionized water was purified by a Milli-Q system (Millipore, Bedford, MA, USA). The lead standard solution (1,000 mg/L) was purchased from Aladdin Industrial Inc. All nucleic acid molecules were prepared by Bioengineering Co., Ltd. (Shanghai). The sequences were as follows:

DNA1: $5^{\prime}>$ AAGGGT GGGT GGGT $<3^{\prime}$

DNA2: 5' >AAAAA AAAAA AAAAA AAAAA TTTTT CACCC TCCC AC $<3^{\prime}$

\section{Synthesis of $\mathrm{NaYF}_{4}: \mathrm{Yb}, \mathrm{Er}$}

The $\mathrm{NaYF}_{4}$ : $18 \% \mathrm{Yb}, 2 \%$ Er UCNPs were prepared according to the previous report ( $\mathrm{Li}$ and Zhang, 2008). Typically, $\mathrm{YCl}_{3}(0.80$ $\mathrm{mmol}), \mathrm{YbCl}_{3}(0.18 \mathrm{mmol}), \mathrm{ErCl}_{3}(0.02 \mathrm{mmol}), \mathrm{OA}(6.0 \mathrm{ml})$, and ODE $(15 \mathrm{ml})$ were mixed and heated to $140^{\circ} \mathrm{C}$ under vacuum for $1 \mathrm{~h}$ before cooling down to room temperature. Thereafter, $\mathrm{NH}_{4} \mathrm{~F}(4.0 \mathrm{mmol})$ and $\mathrm{NaOH}(2.5 \mathrm{mmol})$ in methanol $(10 \mathrm{ml})$ was added to the resulting solution and stirred for $30 \mathrm{~min}$. The mixture was then transferred to a vacuum oven at $70^{\circ} \mathrm{C}$ for $30 \mathrm{~min}$ and heated at $300^{\circ} \mathrm{C}$ under argon flow for $1 \mathrm{~h} . \mathrm{NaYF}_{4}$ : $18 \% \mathrm{Yb}, 2 \%$ Er cores were obtained as final product. As-prepared nanoparticles were washed with ethanol for several times and dispersed in $10 \mathrm{ml}$ of cyclohexane.

\section{Synthesis of $\mathrm{NaYF}_{4}: \mathrm{Yb}, \mathrm{Er} @ \mathrm{NaYF}_{4}$ UCNPs}

To prepare $\mathrm{NaYF}_{4}$ : Yb, Er @NaYF 4 UCNPs, $\mathrm{YCl}_{3}(0.25 \mathrm{mmol})$, OA $(6.0 \mathrm{ml})$, and $\mathrm{ODE}(15 \mathrm{ml})$ were mixed and transferred to a vacuum oven at $140^{\circ} \mathrm{C}$ for $1 \mathrm{~h}$. The solution was added with $\mathrm{NaYF}_{4}: \mathrm{Yb}$, Er initial core solution $(5 \mathrm{ml})$ after cooling down to room temperature and heated at $70^{\circ} \mathrm{C}$ in a vacuum oven for $30 \mathrm{~min}$ to remove cyclohexane. Subsequently, the obtained mixture was further maintained at $280^{\circ} \mathrm{C}$ under argon atmosphere for $1 \mathrm{~h}$. The $\mathrm{NaYF}_{4}$ : Yb, Er @NaYF 4 UCNPs were washed before dispersing in cyclohexane.

\section{Surface Modification of $\mathrm{NaYF}_{4}: \mathrm{Yb}, \mathrm{Er}$ $@ \mathrm{NaYF}_{4}$ UCNPs}

Ligand-free UCNPs were synthesized ahead of DNA modification following the method reported by Bogdan et al. (2011). The oleic acid-capped UCNPs in cyclohexane were centrifuged by adding ethanol as precipitant. Then, $100 \mathrm{mg}$ of UCNPs was mixed with $10 \mathrm{ml}$ water, and the $\mathrm{pH}$ of the solution was adjusted to 4 with $0.1 \mathrm{M}$ hydrochloric acid solution. The solution was extracted three times with diethyl ether after stirring for $2 \mathrm{~h}$, and the nanoparticles obtained were transferred to the aqueous layer and precipitated with acetone. Afterward, the oleic acid-ligand layer was removed and the ligand-free UCNPs were dispersed in water $(5 \mathrm{ml})$.

DNA1 (200 $\mathrm{nmol}$ ) was added to the solution of ligand-free

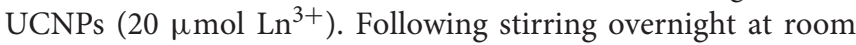
temperature, the mixture was centrifuged to remove excessive DNA1. The resulting DNA1-modified UCNPs were dispersed in Tris- $\mathrm{HCl}$ buffer solution $(20 \mathrm{mM}, 1 \mathrm{mM} \mathrm{MgCl} 2,2 \mathrm{mM} \mathrm{KCl}$, and $100 \mathrm{mM} \mathrm{NaCl}, \mathrm{pH} 7.4$ ) and stored at $4^{\circ} \mathrm{C}$. 


\section{Preparation of DNA2-Modified Au NPs}

$\mathrm{Au}$ NPs were prepared based on the previously reported method (Chen et al., 2012; Pei et al., 2012). The boiling $\mathrm{HAuCl}_{4}$ $\left(\mathrm{HAuCl}_{4} \cdot 4 \mathrm{H}_{2} \mathrm{O}\right.$, 99.99\%) solution was added with trisodium citrate solution (1\%) with $20 \mathrm{~min}$ of stirring and then cooled down to room temperature to obtain Au NPs.

DNA2 was added to citrate-stabilized Au NPs with a stoichiometric ratio of 1:50, and a tiny amount of sodium citratehydrochloric acid buffer solution $(500 \mathrm{mM}, \mathrm{pH} 3.0)$ was then rapidly added to the said mixture to make a final concentration of $10 \mathrm{mM}$. The solution was centrifuged for several times to remove excessive DNA2. DNA2-modified Au NPs were yielded and dispersed in Tris- $\mathrm{HCl}$ buffer solution (20 mM, pH 7.4).

\section{Detection of $\mathrm{Pb}^{2+}$}

The concentration of DNA1-modified UCNPs was immobilized, and DNA2-modified AuNPs with varied concentrations were added to the system. The mixture was incubated for $90 \mathrm{~min}$ at $37^{\circ} \mathrm{C}$. The optimal concentration of AuNPs-DNA2 was determined by the fluorescence quenching efficiency of UCNPs-DNA1.

The $\mathrm{Pb}^{2+}$ standard solution with different concentrations was added to a mixed solution including UCNPs-DNA1 and AuNPs-DNA2, which had been incubated for $90 \mathrm{~min}$. The said solution was further incubated for $30 \mathrm{~min}$ to measure its fluorescence spectra.

\section{Characterization}

Transmission electron microscopy (TEM) images were taken with a JEM-2100F microscope $(200 \mathrm{kV}$, with a Gatan imaging system). The upconversion fluorescence spectra were performed on a Hitachi F4500 fluorescence spectrometer (xenon lamp excitation source with a 980-nm laser). The UV-vis absorption spectra were characterized by a Lambda $750 \mathrm{~S}$ UV/Vis/NIR spectrometer.

\section{RESULTS AND DISCUSSION}

\section{Principle of UCNPs-AuNPs FRET Sensor for the Detection of $\mathrm{Pb}^{2+}$}

The sensor for $\mathrm{Pb}^{2+}$ detection was based on FRET from modified UCNPs to Au NPs by an aptamer matching its complement (Figure 1). Firstly, UCNPs were treated with hydrochloric acid to remove the hydrophobic surface ligands and modified with the aptamers (DNA1). Au NPs were functionalized with the complementary DNA (DNA2). Secondly, the FRET system was established with UCNPs as donors and Au NPS as receptors. The distance between UCNPs and Au NPs was shortened to $<10 \mathrm{~nm}$ because of complementary DNA hybridization, leading to quenched fluorescence of UCNPs. Thirdly, the aptamers preferred to bind with metal ions and turned into intermolecular G-quadruplexes in the presence of $\mathrm{Pb}^{2+}$. Therefore, the DNA duplexes were unwound and upconversion fluorescence was restored to determine the concentration of $\mathrm{Pb}^{2+}$

\section{Characterization of DNA-Modified Nanoparticles}

The $\mathrm{NaYF}_{4}: 18 \% \mathrm{Yb}, 2 \%$ Er with a diameter of $45 \mathrm{~nm}$ was fabricated by the solvent-thermal method in Figure $2 \mathrm{~A}$ ( $\mathrm{Li}$ et al., 2014) and further coated with the $\mathrm{NaYF}_{4}$ passivation shell for the formation of $\mathrm{NaYF}_{4}: 18 \% \mathrm{Yb}, 2 \% \mathrm{Er} @ \mathrm{NaYF}_{4}$ core/shell-structured UCNPs with a diameter of about $50 \mathrm{~nm}$ (Figure 2B). The OA ligands capped on UCNPs were treated

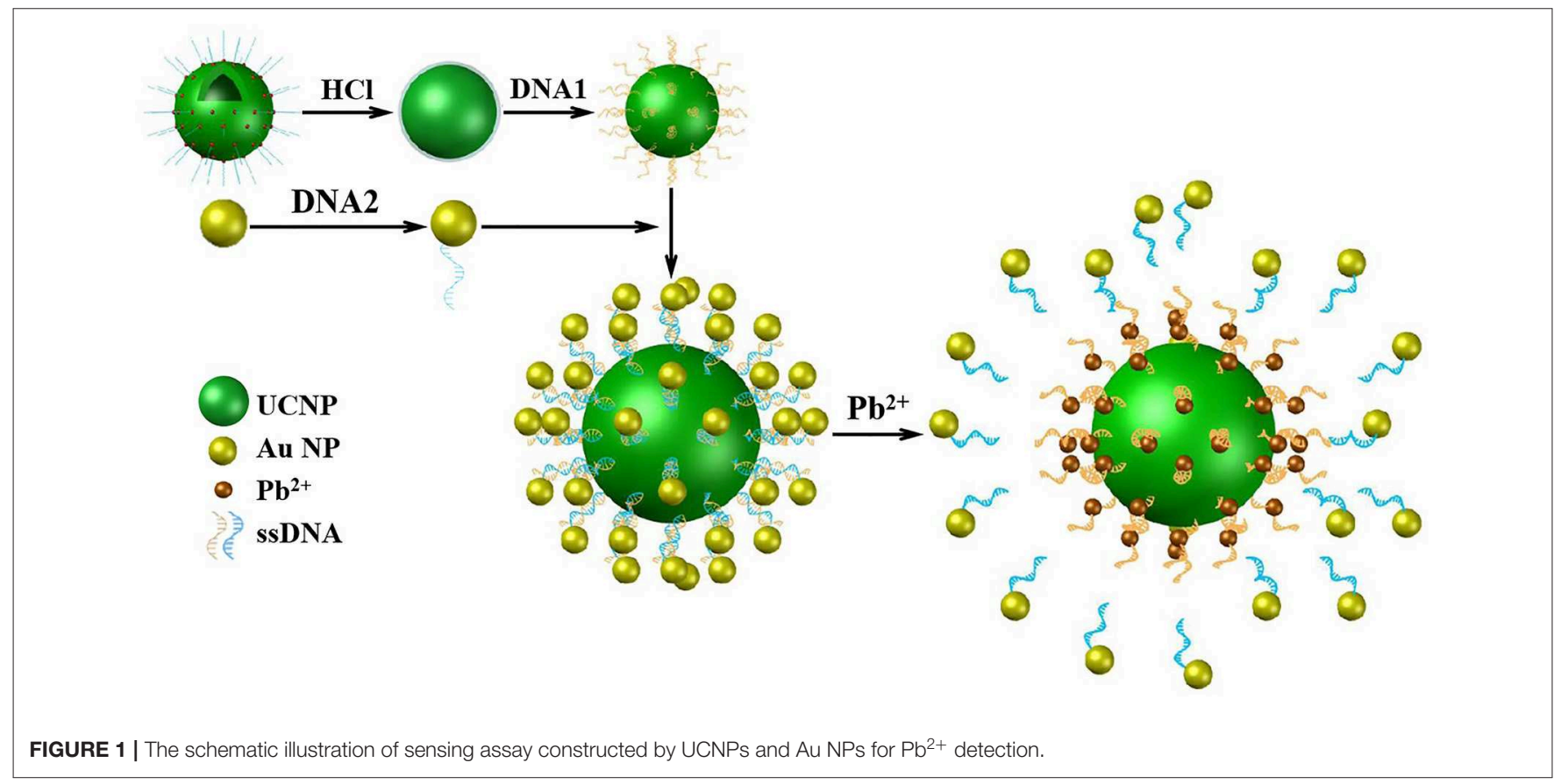



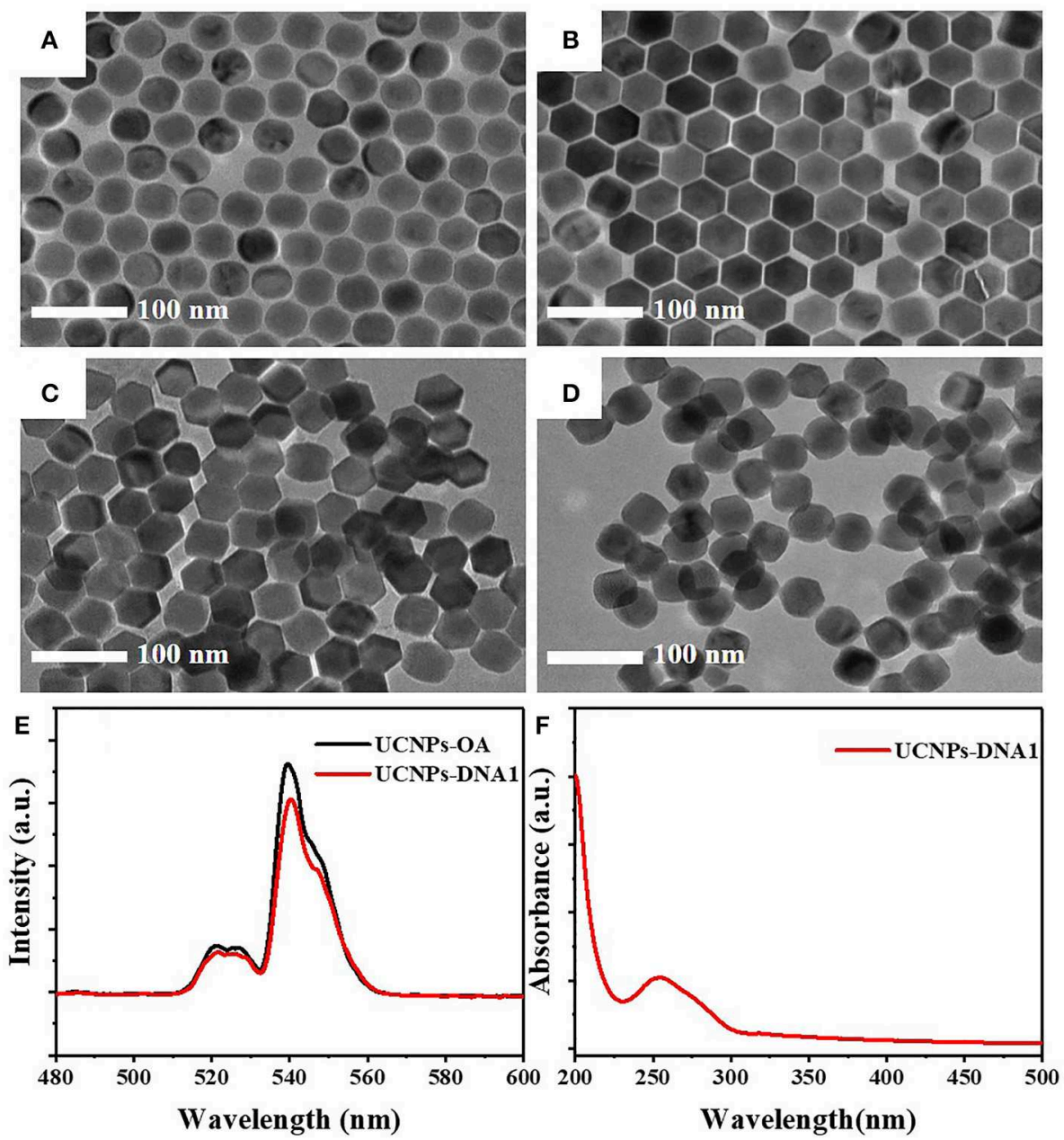

FIGURE 2 | TEM images of (A) NaYF 4 : 18\% Yb and 2\% Er, (B) NaYF 4 : 18\% Yb and 2\% Er @NaYF , (C) ligand-free UCNPs, and (D) DNA1-modified UCNPs (UCNPs-DNA1). (E) The upconversion fluorescence spectra of UCNPs with OA surface ligand (UCNPs-OA) and DNA aptamers (UCNPs-DNA1) under excitation of $980 \mathrm{~nm}$. (F) The UV-vis absorption spectra of UCNPs-DNA1.

with hydrochloric acid to form the water-soluble ligandfree UCNPs (Figure 2C). The TEM image shows that the obtained water-soluble ligand-free UCNPs remained uniform and monodispersed. Upon DNA1 modification, the UCNPs retained good dispersion with negligible morphological and size alteration (Figure 2D). The fluorescence of UCNPs was slightly quenched by water after being modified with DNA1 (Figure 2E). A strong absorption peak at $260 \mathrm{~nm}$ from the DNA was clearly observed in the spectrum of the DNA1-modified UCNPs, confirming that the UCNPs were successfully modified with DNA-1 (Figure 2F).

$\mathrm{Au}$ NPs with a diameter of $10 \mathrm{~nm}$ (Figure 3A) were modified with DNA2 molecules, which were partially complementary with DNA1. The DNA2-modified Au NPs remained of good dispersion (Figure 3B). The significant DNA absorption peak was observed at $260 \mathrm{~nm}$, while the maximum absorption peak of $\mathrm{Au}$ NPs at $520 \mathrm{~nm}$ presented no significant variation (Figure 3C). A spectral overlap was illustrated in the range of $510-570 \mathrm{~nm}$ between UCNPs and Au NPs (Figure 3D).

\section{Optimization of FRET System}

The fluorescence intensity of UCNPs gradually decreases along with the elevation of DNA2-modified Au NPs (Figure 4A). The concentration of UCNPs was fixed at $6.56 \mathrm{mg} / \mathrm{L}$ accompanied by adjusting the concentration of $\mathrm{Au}$ NPs. The quenching efficiency of upconversion fluorescence climbed up to $80 \%$ at a concentration of $99.75 \mathrm{nM}$ and remained stable at higher concentrations (Figure 4B). Therefore, the optimal concentration of the DNA2-modified Au NPs is $99.75 \mathrm{nM}$. In Figure $4 \mathrm{C}$, the UCNPs are surrounded by $\mathrm{Au}$ NPs, indicating the construction of the FRET system between UCNPs and $\mathrm{Au}$ NPs. Moreover, the fluorescence quenching efficiency reached a plateau (80\%) after 90 min of incubation (Figure 4D). Therefore, $90 \mathrm{~min}$ of incubation is adopted to achieve a stable fluorescence signal.

\section{Detection of $\mathrm{Pb}^{2+}$}

The optimal concentrations of UCNPs $(6.56 \mathrm{mg} / \mathrm{L})$ and $\mathrm{Au}$ NPs $(99.75 \mathrm{nM})$ were chosen for the detection system. After 

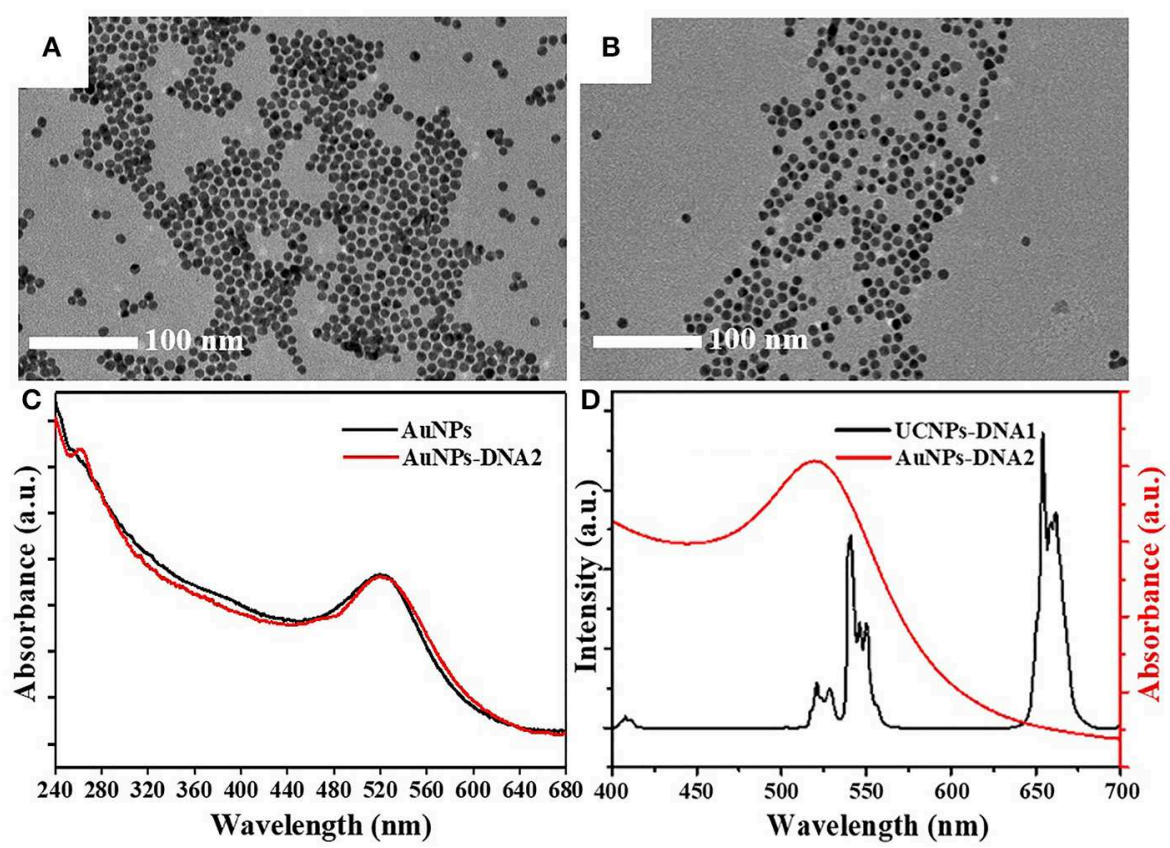

FIGURE 3 | TEM images of (A) Au NPs and (B) DNA2-modified Au NPs (Au NPs-DNA2). (C) The UV-vis absorption spectra of Au NPs and Au NPs-DNA2. (D) The upconversion fluorescence spectra of UCNPs-DNA1 and the UV-vis absorption spectra of Au NPs-DNA2.
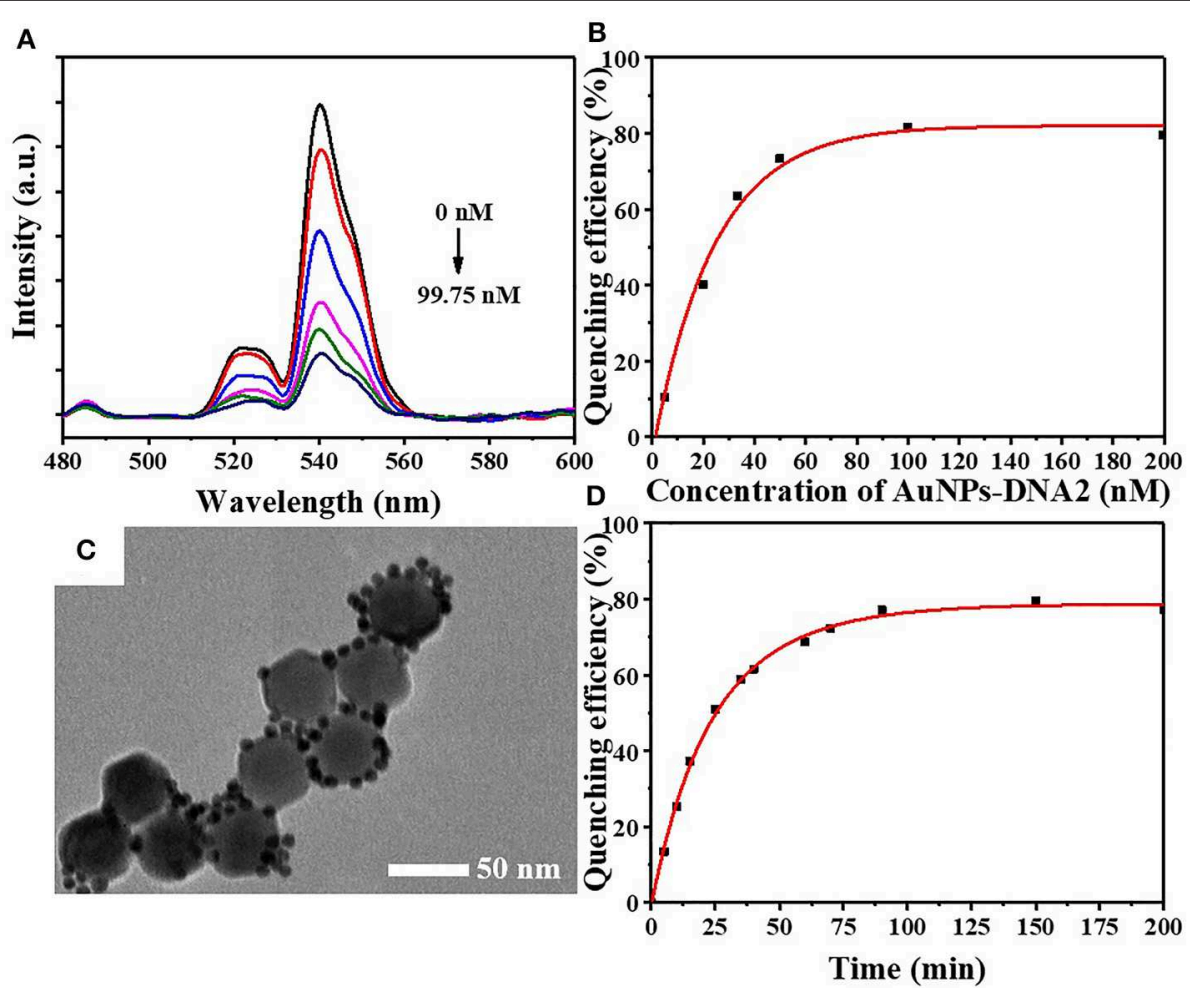

FIGURE 4 | (A) The upconversion fluorescence spectra and (B) quenching efficiency of UCNPs-DNA1 after incubation at various concentrations of AuNPs-DNA2 in FRET system. (C) TEM image of FRET array fabricated from UCNPs-DNA1 and AuNPs-DNA2. (D) The fluorescence quenching efficiency with increasing incubation time. 
adding the lead standard solution to the system, the DNA aptamers on the surface of the UCNPs were induced to form G-quadruplexes by $\mathrm{Pb}^{2+}$, leading to the double-stranded DNA unwinding. Subsequently, the energy transfer system between the UCNP energy donors and Au NP receptors was broken, and the upconversion fluorescence was regained (Figures 5A,B). The fluorescence is restored gradually along with the elevation of concentration (Figure 5C). Linear correlation was demonstrated between the recovery of fluorescence and the concentration of
$\mathrm{Pb}^{2+}$ in the range of 0 and $50 \mathrm{nM}$ (Figure 5D). Determined to be $3 \sigma$, the detection limit of the sensor is $4.1 \mathrm{nM}$. According to the Guidelines for Drinking-water Quality in 2017, the $\mathrm{Pb}^{2+}$ concentration was recommended to be no more than $10 \mathrm{ppb}$ or $48 \mathrm{nM}$ (World Health Organization, 2017). Therefore, this study elucidated a great potential of the developed FRET-based assay for in situ detection of $\mathrm{Pb}^{2+}$ in practice. The effect of $\mathrm{Pb}^{2+}$ on upconversion fluorescence was demonstrated by adding different concentrations of heavy metal ions. There is no significant effect
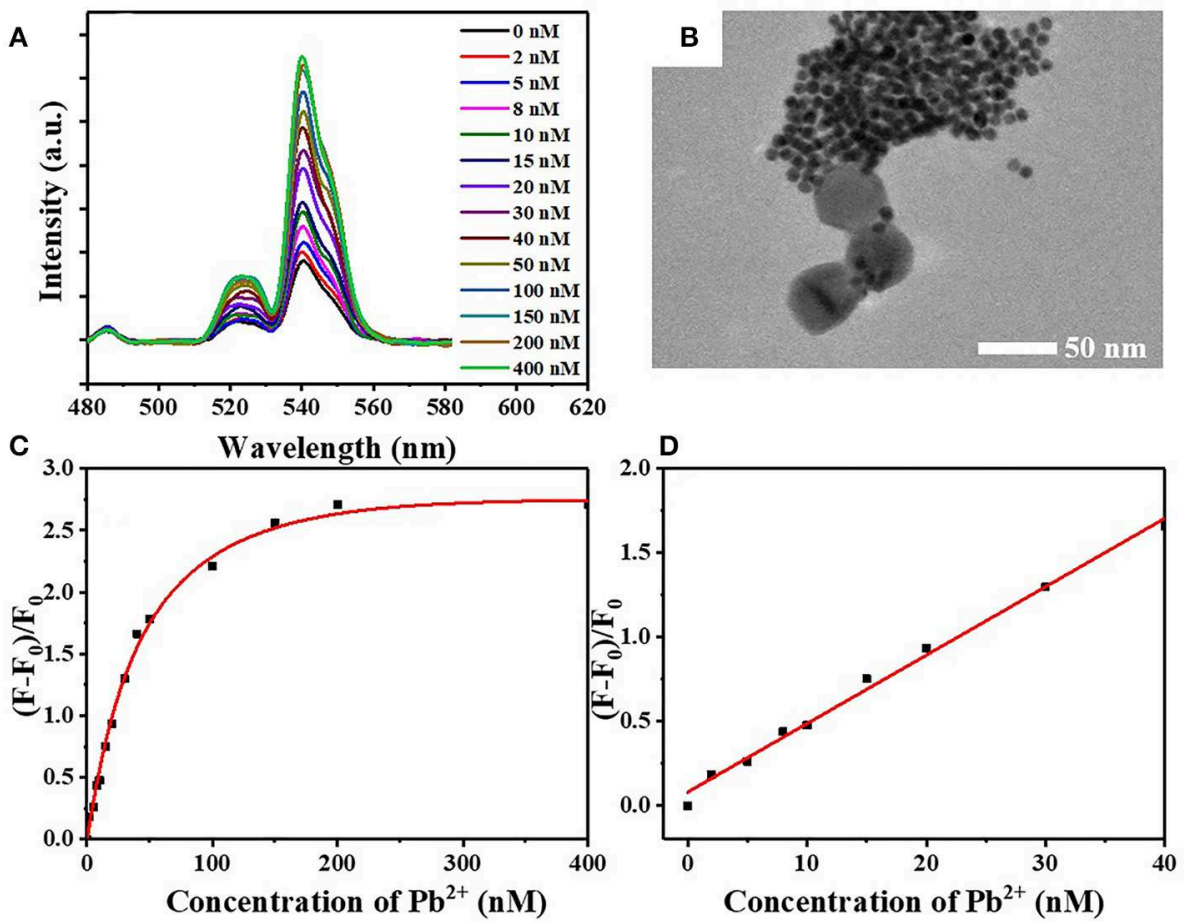

FIGURE 5 | (A) The restoration of fluorescence after incubation at different concentrations of $\mathrm{Pb}^{2+}$ in FRET system. (B) TEM image of FRET array fabricated from UCNPs-DNA1 and AuNPs-DNA2 after $\mathrm{Pb}^{2+}$ incorporation. (C) The relationship between relative fluorescence intensity $\left(\mathrm{F}-\mathrm{F}_{0}\right) / \mathrm{F}_{0}$ and $\mathrm{Pb}^{2+}$ concentration. (D) Linear correlation between relative fluorescence intensity $\left(\mathrm{F}-\mathrm{F}_{0}\right) / \mathrm{F}_{0}$ and $\mathrm{Pb}^{2+}$ concentration in the range of $0-50 \mathrm{nM}$.
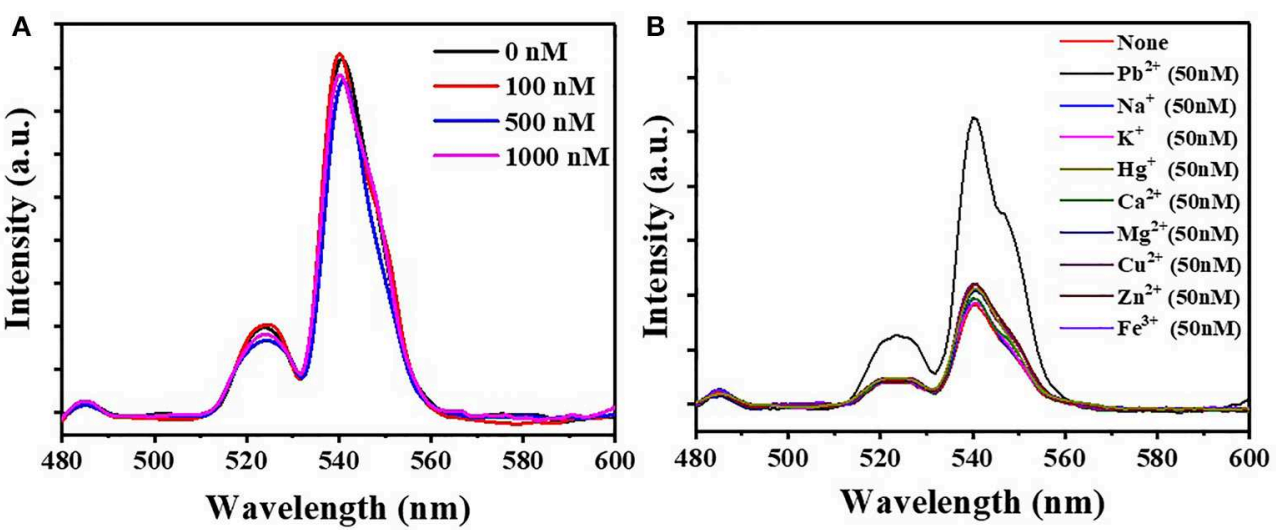

FIGURE 6 | (A) The fluorescence intensity of FRET array after incubation at different concentrations of $\mathrm{Pb}^{2+}$. (B) The fluorescence intensity of detection sensor after the incorporation of $\mathrm{Pb}^{2+}, \mathrm{K}^{+}, \mathrm{Na}^{+}, \mathrm{Ca}^{2+}, \mathrm{Mg}^{2+}, \mathrm{Hg}^{2+}, \mathrm{Cu}^{2+}, \mathrm{Zn}^{2+}$, and $\mathrm{Fe}^{3+}$ 
on upconversion fluorescence, even if the $\mathrm{Pb}^{2+}$ concentration was increased up to $1,000 \mathrm{nM}$ (Figure 6A).

\section{Validation of Selectivity}

The selectivity of the sensor for the detection of $\mathrm{Pb}^{2+}$ was also tested with different metal ions (Figure 6B, Figure $\mathbf{S 1}$ ). $\mathrm{Pb}^{2+}$ ions led to a dramatic fluorescence recovery (177.9\%), while metal ions including $\mathrm{K}^{+}, \mathrm{Na}^{+}, \mathrm{Ca}^{2+}, \mathrm{Mg}^{2+}, \mathrm{Hg}^{2+}, \mathrm{Cu}^{2+}, \mathrm{Zn}^{2+}$, and $\mathrm{Fe}^{3+}$ presented little restoration in the fluorescence spectrum. The result demonstrated the high selectivity of the FRET system for $\mathrm{Pb}^{2+}$ detection.

\section{CONCLUSIONS}

In summary, a highly sensitive $\mathrm{Pb}^{2+}$ detection sensor was constructed based on FRET between UCNPs as donors and $\mathrm{Au}$ NPs as receptors. The hydrophobic surface ligands of $\mathrm{NaYF}_{4}: 18 \% \mathrm{Yb}, 2 \% \mathrm{Er} @ \mathrm{NaYF}_{4}$ were removed by hydrochloric acid, resulting in enhanced water-dispersible UCNPs which were further modified with DNA1. Au NPs prepared and modified with DNA2, which was partially complementary with DNA1. The FRET assay was fabricated by hybridizing two complementary DNA strands; thus, the green fluorescence of UCNPs was quenched. The specific $\mathrm{Pb}^{2+}$ detection was due to the formation of G-quadruplexes derived from the preferred binding between aptamers of UCNPs and $\mathrm{Pb}^{2+}$, leading to unwound DNA for the recovery of fluorescence. There was a distinct linear correlation between the relative fluorescence intensity and the concentration of $\mathrm{Pb}^{2+}$ from 0 to

\section{REFERENCES}

Bogdan, N., Vetrone, F., Ozin, G. A., and Capobianco, J. A. (2011). Synthesis of ligand-free colloidally stable water dispersible brightly luminescent lanthanide-doped upconverting nanoparticles. Nano Lett. 11, 835-840. doi: $10.1021 /$ nl1041929

Bravo-Sanchez, L. R., De La Riva, B. S., Costa-Fernandez, J. M., Pereiro, R., and Sanz-Medel, A. (2001). Determination of lead and mercury in sea water by preconcentration in a flow injection system followed by atomic absorption spectrometry detection. Talanta 55, 1071-1078. doi: 10.1016/S0039-9140(01)00523-9

Chang, H., Tang, L., Wang, Y., Jiang, J., and Li, J. (2010). Graphene fluorescence resonance energy transfer aptasensor for the thrombin detection. Anal. Chem. 82, 2341-2346. doi: 10.1021/ac90 25384

Chen, G., Qju, H., Prasad, P. N., and Chen, X. (2014). Upconversion nanoparticles: design, nanochemistry, and applications in theranostics. Chem. Rev. 114, 5161-5214. doi: 10.1021/cr400425h

Chen, G., Song, F., Xiong, X., and Peng, X. (2013). Fluorescent nanosensors based on Fluorescence Resonance Energy Transfer (FRET). Industr. Eng. Chem. Res. 52, 11228-11245. doi: 10.1021/ie30 $3485 n$

Chen, J., and Zhao, J. X. (2012). Upconversion nanomaterials: synthesis, mechanism, and applications in sensing. Sensors 12, 2414-2435. doi: 10.3390/s120302414

Chen, Z., Ren, X., Meng, X., Zhang, Y., Chen, D., and Tang, F. (2012). Novel fluorescence method for detection of alpha-L-fucosidase based on CdTe quantum dots. Anal. Chem. 84, 4077-4082. doi: 10.1021/ac300166n

Dacosta, M. V., Doughan, S., Han, Y., and Krull, U. J. (2014). Lanthanide upconversion nanoparticles and applications in bioassays and bioimaging:
$50 \mathrm{nM}$. The developed sensor also presented superior sensitivity $(4.1 \mathrm{nM})$ and selectivity, indicating a promising perspective for $\mathrm{Pb}^{2+}$ detection.

\section{DATA AVAILABILITY STATEMENT}

All datasets generated for this study are included in the article/Supplementary Material.

\section{AUTHOR CONTRIBUTIONS}

YW: formal analysis, investigation. ML: validation. ZC: software. ZD: data analysis, overall planning, and revision of the manuscript. NL: methodology. JF: conceptualization and methodology. WZ: supervision. All authors wrote and reviewed the manuscript.

\section{FUNDING}

This work was supported by the National Natural Science Foundation of China (51878472), and the State Key Laboratory of Pollution Control and Resource Reuse Foundation (No. PCRRK 18001).

\section{SUPPLEMENTARY MATERIAL}

The Supplementary Material for this article can be found online at: https://www.frontiersin.org/articles/10.3389/fchem. 2020.00238/full\#supplementary-material

a review. Anal. Chim. Acta 832, 1-33. doi: 10.1016/j.aca.2014. 04.030

Gao, R., Hu, Z., Chang, X., He, Q., Zhang, L., Tu, Z., et al. (2009). Chemically modified activated carbon with 1-acylthiosemicarbazide for selective solid-phase extraction and preconcentration of trace $\mathrm{Cu}(\mathrm{II})$, $\mathrm{Hg}(\mathrm{II})$ and $\mathrm{Pb}(\mathrm{II})$ from water samples. J. Hazard. Mater. 172, 324-329. doi: 10.1016/j.jhazmat.2009.07.014

Haase, M., and Schaefer, H. (2011). Upconverting nanoparticles. Angew. Chem. Int. Edn. 50, 5808-5829. doi: 10.1002/anie.201005159

Hamaguchi, N., Ellington, A., and Stanton, M. (2001). Aptamer beacons for the direct detection of proteins. Anal. Biochem. 294, 126-131. doi: 10.1006/abio.2001.5169

Kim, H. N., Ren, W. X., Kim, J. S., and Yoon, J. (2012). Fluorescent and colorimetric sensors for detection of lead, cadmium, and mercury ions. Chem. Soc. Rev. 41, 3210-3244. doi: 10.1039/c1cs15245a

Li, X., Wang, R., Zhang, F., and Zhao, D. (2014). Engineering homogeneous doping in single nanoparticle to enhance upconversion efficiency. Nano Lett. 14, 3634-3639. doi: 10.1021/nl501366x

Li, X., Xu, B., Lu, H., Wang, Z., Zhang, J., Zhang, Y., et al. (2013). Labelfree fluorescence turn-on detection of $\mathrm{Pb} 2+$ based on AIE-active quaternary ammonium salt of 9,10-distyrylanthracene. Anal. Methods 5, 438-441. doi: $10.1039 / \mathrm{c} 2 \mathrm{ay} 26202 \mathrm{a}$

Li, Z., and Zhang, Y. (2008). An efficient and user-friendly method for the synthesis of hexagonal-phase $\mathrm{NaYF}(4): \mathrm{Yb}$, Er/Tm nanocrystals with controllable shape and upconversion fluorescence. Nanotechnology 19, 345606-345606. doi: 10.1088/0957-4484/19/34/345606

Lin, F., Yin, B., Li, C., Deng, J., Fan, X., Yi, Y., et al. (2013). Fluorescence resonance energy transfer aptasensor for platelet-derived growth factor detection based on upconversion nanoparticles in 30\% blood serum. Anal. Methods 5, 699-704. doi: 10.1039/C2AY25519G 
Liu, B., Tan, H., and Chen, Y. (2013). Upconversion nanoparticle-based fluorescence resonance energy transfer assay for $\mathrm{Cr}$ (III) ions in urine. Anal. Chim. Acta 761, 178-185. doi: 10.1016/j.aca.2012.11.035

Mader, H. S., Kele, P., Saleh, S. M., and Wolfbeis, O. S. (2010). Upconverting luminescent nanoparticles for use in bioconjugation and bioimaging. Curr. Opin. Chem. Biol. 14, 582-596. doi: 10.1016/j.cbpa.2010. 08.014

Pavlov, V., Xiao, Y., Shlyahovsky, B., and Willner, I. (2004). Aptamerfunctionalized $\mathrm{Au}$ nanoparticles for the amplified optical detection of thrombin. J. Am. Chem. Soc. 126, 11768-11769. doi: 10.1021/ja04 $6970 \mathrm{u}$

Pei, H., Li, F., Wan, Y., Wei, M., Liu, H., Su, Y., et al. (2012). Designed diblock oligonucleotide for the synthesis of spatially isolated and highly hybridizable functionalization of DNA-gold nanoparticle nanoconjugates. J. Am. Chem. Soc. 134, 11876-11879. doi: 10.1021/ja304118z

Peng, J., Wang, Y., Wang, J., Zhou, X., and Liu, Z. (2011). A new biosensor for glucose determination in serum based on up-converting fluorescence resonance energy transfer. Biosens. Bioelectr. 28, 414-420. doi: 10.1016/j.bios.2011.07.057

Saha, K., Agasti, S. S., Kim, C., Li, X., and Rotello, V. M. (2012). Gold nanoparticles in chemical and biological sensing. Chem. Rev. 112, 2739-2779. doi: $10.1021 / \mathrm{cr} 2001178$

Wang, L. Y., Yan, R. X., Hao, Z. Y., Wang, L., Zeng, J. H., Bao, J., et al. (2005). Fluorescence resonant energy transfer biosensor based on upconversion-luminescent nanoparticles. Angew. Chem. Int. Edn. 44, 6054-6057. doi: 10.1002/ange.200501907

World Health Organization (2017). Guidelines for Drinking-Water Quality: Fourth Edition, Incorporating The First Addendum. World Health Organization.

Wu, S., Duan, N., Shi, Z., Fang, C., and Wang, Z. (2014). Dual fluorescence resonance energy transfer assay between tunable upconversion nanoparticles and controlled gold nanoparticles for the simultaneous detection of $\mathrm{Pb}^{2+}$ and $\mathrm{Hg}^{2+}$. Talanta 128, 327-336. doi: 10.1016/j.talanta.2014. 04.056

Xia, L., Li, X., Wu, Y., Hu, B., and Chen, R. (2008). Ionic liquids based single drop microextraction combined with electrothermal vaporization inductively coupled plasma mass spectrometry for determination of $\mathrm{Co}, \mathrm{Hg}$ and $\mathrm{Pb}$ in biological and environmental samples. Spectrochim. Acta B 63, 1290-1296. doi: 10.1016/j.sab.2008.09.018

Xiao, Y., Lubin, A. A., Heeger, A. J., and Plaxco, K. W. (2005). Label-free electronic detection of thrombin in blood serum by using an aptamerbased sensor. Angew. Chem. Int. Edn. 44, 5456-5459. doi: 10.1002/ange.2005 00989

Yang, G., Zhang, C. M., Hu, Q. F., and Yin, J. Y. (2003). Simultaneous determination of four heavy metal ions in tobacco and tobacco additive by online enrichment followed by RP-HPLC and microwave digestion. J. Chromatogr. Sci. 41, 195-199. doi: 10.1093/chromsci/41.4.195

Yoosaf, K., Ipe, B. I., Suresh, C. H., and Thomas, K. G. (2007). In situ synthesis of metal nanoparticles and selective naked-eye detection of lead ions from aqueous media. J. Phys. Chem. C 111, 12839-12847. doi: 10.1021/jp07 $3923 \mathrm{q}$

Zhan, S., Wu, Y., Liu, L., Xing, H., He, L., Zhan, X., et al. (2013). A simple fluorescent assay for lead(II) detection based on lead(II)-stabilized G-quadruplex formation. Rsc Adv. 3, 16962-16966. doi: 10.1039/C3RA4 2621A

Zheng, X., Yao, T., Zhu, Y., and Shi, S. (2015). $\mathrm{Cu}^{2+}$ modulated silver nanoclusters as an on-off-on fluorescence probe for the selective detection of L-histidine. Biosens. Bioelectr. 66, 103-108. doi: 10.1016/j.bios.2014.11.013

Zhou, R., Li, B., Wu, N., Gao, G., You, J., and Lan, J. (2011). Cyclen-functionalized perylenebisimides as sensitive and selective fluorescent sensors for $\mathrm{Pb} 2+$ in aqueous solution. Chem. Commun. 47, 6668-6670. doi: 10.1039/c1cc11200g

Conflict of Interest: The authors declare that the research was conducted in the absence of any commercial or financial relationships that could be construed as a potential conflict of interest.

Copyright (c) 2020 Wang, Lv, Chen, Deng, Liu, Fan and Zhang. This is an open-access article distributed under the terms of the Creative Commons Attribution License (CC BY). The use, distribution or reproduction in other forums is permitted, provided the original author(s) and the copyright owner(s) are credited and that the original publication in this journal is cited, in accordance with accepted academic practice. No use, distribution or reproduction is permitted which does not comply with these terms. 